\title{
Student Financial Literacy: A Review of Gender Differences and Parent's Income
}

\author{
Dadang Saepuloh ${ }^{1, *}$ Disman $^{2,}$ Suwatno $^{3,}$ Eeng Ahman $^{4}$ \\ ${ }^{1}$ Universitas Islam Syekh-Yusuf \\ ${ }^{2}$ Universitas Pendidikan Indonesia \\ ${ }^{3}$ Universitas Pendidikan Indonesia \\ ${ }^{4}$ Universitas Pendidikan Indonesia \\ *Corresponding author. Email: dsaepuloh@unis.ac.id
}

\begin{abstract}
Competition in 21 st-century society is very tight. To survive the competition that occurs, there is a solution to develop: financial literacy. Indonesia is one of the countries that are relatively low on financial literacy com-pared to other countries, according to The World Bank survey results in 2015. Today, the phenomenon shows that youth financial management is still low, especially at the high school / vocational level. The purpose of this study was to determine whether there were differences in financial literacy according to gender and par-ents' income in Sepatan District. This study uses a quantitative comparative method, with a sample of 371 students using Proportionate Stratified Random Sampling on state and private high school students in Sepatan District. Data collection instruments employed questionnaires in the form of student personal data. The results showed that: (1) the level of students' financial literacy is in the medium category; (2) there is no difference in students' financial literacy according to gender and parents' income.
\end{abstract}

Keywords: financial literacy, gender, parental income.

\section{INTRODUCTION}

Today, financial literacy is popular among researchers at both national and international levels. Jappelli \& Padula, (2013) revealed that financial literacy is a decision to choose financial planning and understand financial services utilization [1]. Financial literacy is a life skill that is necessary to improve financial well-being at all stages of life. Financial literacy capabilities are required by all communities anywhere, so it is part of the global policy agenda [2]. Financial literacy is an individual's ability to make the right decisions based on information obtained [3]. Students experience the transition from adolescence to early adulthood, so that students are required to be self-reliant in managing personal finances, not to be dependent upon their parents. Consumers make irrational purchases in fulfilling their needs, including children and Adolescents [4]. In line with Lusardi \& Mitchell (2009), every individual should be able to decide finances. This decision is interconnected with the importance of financial literacy as a provision of one [5]. Managing personal finances becomes very important nowadays, and individuals must plan short-term and long-term investments [6]. Individuals with high financial attitudes are more likely to have a positive attitude toward financial planning [5].

Low financial literacy in conducting economic activities is a fundamental problem that has a farreaching impact on the Nation's progress [7]. As Atkinson (2010) expressed, the community's financial literacy ability is still less, especially in developing countries [8]. Various surveys or research studies have been conducted to determine the community's financial literacy in Indonesia. One of them is a survey of financial literacy Research in 2006 - 2016 by the Otoritas Jasa Keuangan (Financial Services Authority) (2016) on the Indonesian population as seen in Figure 1.

Index of Indonesia's financial literacy in the year $2006-2010$ is well literate of $7.21 \%$, including into low category. In the years $2011-2012$, suffered a decline of $6.30 \%$. In the years $2013-2014$ in-creased by $9.01 \%$. In 2015 - 2016, the Financial literacy Index of Indonesian 
people experienced a significant increase to $77.48 \%$ by the beginning of many Indonesians who use financial services. Like the survey OJK (2017) recorded, Indonesian students' financial literacy is only $28 \%$. It means that from 100 children, only 28 children know about financial literacy, including savings. The child index has a savings of only $44 \%$ based on the Financial Services Authority survey.

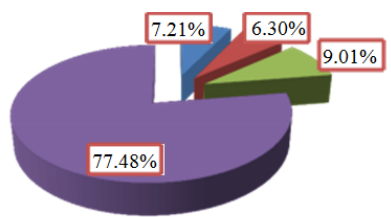

ロ2006-2010 $2011 \quad-20122013 \quad-20142015 \quad-2016$

Figure 1 Indonesian Financial Literacy Index of Indonesia year 2006 - 2016

People who have participated in financial education will have a basic knowledge of some key financial concepts [2]. Therefore, financial knowledge is referred to as the primary dimension of financial literacy [11]. Lack of knowledge of financial literacy can cause mistakes when making decisions in the financial problems faced. It is expressed by [12] in their research results that a good knowledge of financial literacy leads to a smarter choice in saving and investing. The school's implementation of financial education has at least a shortterm effect on financial expenditure attitudes and behaviors [13] because the school is the first foundation in developing and growing financial literacy to its students. The level of financial literacy in primarily adolescent children tends to be low, affecting individuals and socially. After the global financial crisis, lack of knowledge of finances has become a concern around the world today [12]. Thus, it became essential financial education was grown from an early age in line with the expressed Batty et al. (2015) that there is an influence in providing financial education to children to develop skills in the success of managing their finances in the future [13].

The OCDE council meeting in 2014 in Paris discussed gender equality in education as a vital issue in its agenda [14]. Gender is a trait inherent in men and women's social and cultural constructional [15]. Relating to the gender of men and women, there has been many inequalities and the distinction [16]. In general, gender differences from female groups are more comfortable to feel the emotional male-type because they make decisions based on their rationality [17]. There is a significant difference in the level of financial literacy between males and females, suggesting that women usually lack fi-nancial male-type information [18]. Based on gender equality in education, it becomes exciting to explore how large the gender gap in students' financial literacy from various literations is. For instance, Banco de $P$ (2010) in Nicolini (2013) found that women's financial literacy rate was lower than that of men [19].

In contrast to these research results, Aisyah \& Saepuloh (2019) revealed that women's Islamic financial literacy is higher than men's [20]. This study is in line with Garg \& Singh (2018) that women have higher literacy levels. In comparison to the results of the study above Suherman (2020), stating that female or male students have no distinction in the knowledge of financial literacy, these results are in line with Homan (2015), which shows that there is no dif-ference in financial literacy between male stu-dents and female students, this phenomenon is fascinating to be examined because of differ-ences between previous researchers.

Low financial understanding can be seen in behaviors that do not consider the financial management of spending money for some stu-dents, regardless of the economic condition of his parents' income, according to Gilarso in Sofia \& Irianto (2016). Parents ' income is income in the form of money in units of rupiah re-ceived as a reward from formal and informal sector activities for one month [25], likewise ex-plained through the research conducted by Nidar \& Bestari (2012) and Margaretha \& Pambudhi, (2015) found that parents ' income does not affect financial literacy. This suggests that high parental income is not a predictor of the high level of individual financial literacy. Parents ' income is the benchmark of students in conducting their financial management to spend money to fulfill their daily needs, the income of parents has a significant impact on financial lit-eracy Sulaiman, (2015) as well as the results of the research Sofia \& Irianto, (2016) which states the income of parents significant influence on financial literacy. However, this research is not in line with the research conducted by Homan (2015) that there is no correlation between the income level of parents with financial literacy. The results are reconfirmed Radityas \& Pustikaningsih (2019) stated that the parental income level does not affect financial literacy.

Based on the background, researchers de-cided to employ data collection with a survey method. A questionnaire was spread and ana-lyzed descriptively. It is conducted for students in high school and vocational school in Sepatan Subdistrict. The purpose of this study was to find out whether or not there are differences in financial literacy by gender and income of par-ents in Sepatan subdistrict.

\section{METHODS}

The method used in this research is a survey of students in SMA and SMK that is in the Sepatan Kecapatan with a student population in 4 schools with 5,112 students. Sampling using techniques from Probability sampling is a Pro-portionate Stratified Random Sampling to 371 samples. Data analysis 
methods use comparative descriptive. According to statistics, the Financial literacy questionnaire amounted to 24 questions and has been carried out the validity and reusability test. The reusability test results have the coefficient value of Alpha Cronbach 0.840 be-longs to the category very strong.

\section{RESULTS AND DISCUSSION}

\subsection{Preterm analysis}

Before conducting data analysis, first done test the normality and test the homogeneity as in Table 1.

Table 1. Normality test

\begin{tabular}{|c|c|c|c|c|}
\hline \multirow{2}{*}{ Variabel } & & \multicolumn{3}{|l|}{ Shapiro-Willk } \\
\hline & & Statistic & df & sig. \\
\hline Financial & & ,983 & 71 & ,465 \\
\hline \multirow{2}{*}{ Gender } & Male & 989 & 124 & ,459 \\
\hline & Female & 989 & 147 &, 057 \\
\hline \multirow[t]{3}{*}{ Parent Income } & Rp. 5000.000 & 993 & 311 &, 132 \\
\hline & $\begin{array}{l}\text { Rp. } 5000.000 \text { - } \\
10.000 .000\end{array}$ & 979 & 53 &, 471 \\
\hline & $>\mathrm{Rp} \cdot 10.000 .000$ & 899 & 7 &, 327 \\
\hline
\end{tabular}

Based on the results above indicates that the significance of Shapiro-Wilk values assuming $>0,05 \mathrm{in}$ the research variables include: financial literacy $(0,465>$ $0.05)$. Male gender $>0.05(0,459>0.05)$, for the significance of women's values $>0.05(0.57>0.05)$ and parents ' income < RP. $5.000 .000(0,132>0.05)$, RP. 5.000.000-Rp. $10.000 .000(0,471>0.05)$ and > RP. $10.000 .000(0,327>0.05)$. So it can be concluded that financial literacy, male and female gender, as well as parents ' income are distributed normally.

Table 2. Homogeneity test

\begin{tabular}{ccccc}
\hline Variabel & $\begin{array}{c}\text { Levena } \\
\text { Statistic }\end{array}$ & df1 & df2 & sig. \\
\hline $\begin{array}{c}\text { Financial } \\
\text { Literacy } \\
\text { Gender }\end{array}$ &, 143 & 1 & 369 &, 706 \\
Parent Income &, 087 & 1 & 369 &, 768 \\
\hline
\end{tabular}

Based on the above output can be seen the significance value for testing homogeneity assuming > 0.05 include: financial literacy $(0,706>0.05)$, gender $>$ $0.05(0,768>0.05)$ and parental education $>0.05(0,544$ $>0.05)$. Thus, it can be concluded that a variable of financial literacy, gender and parental income has the same or homogeneous variance.

\subsection{Data Analysis}

The parent's income, gender Data in the study uses comparative analysis, Namut for financial literacy measurement using quantitative descriptors.

Table 3. Independent financial literacy test samples according to gender

\begin{tabular}{cccccc}
\hline & \multicolumn{5}{c}{$\begin{array}{c}\text { Levene's Test for } \\
\text { Equality of } \\
\text { Variances }\end{array}$} \\
\cline { 2 - 6 } Assumed & $\mathrm{F}$ & Sig. & $\mathrm{t}$ & $\mathrm{df}$ & $\begin{array}{c}\text { Sig. (2- } \\
\text { tailed) }\end{array}$ \\
\cline { 2 - 6 } $\begin{array}{c}\text { Equal } \\
\text { variances } \\
\text { assumed } \\
\text { Equal } \\
\text { variances } \\
\text { not } \\
\text { assumed }\end{array}$ & 2,067 &, 151 & $-1,773$ & 369 &, 142 \\
\hline
\end{tabular}

Based on the output result above, the significance 0.142 . Thus, the significance of $>0.05(0,142>0.05)$ is then HO acceptable. So it can be concluded that the gender data group among men and women has the same variance, so Test $\mathrm{T}$ (Independent Sample T-Test) using the equal value variance assumed.

Table 4. Financial literacy and parental income

\begin{tabular}{cccccc}
\hline & \multicolumn{5}{c}{$\begin{array}{c}\text { Levene's Test for } \\
\text { Equality of } \\
\text { Variances }\end{array}$} \\
\cline { 2 - 6 } Assumed & F & Sig. & t & df & $\begin{array}{c}\text { Sig. (2- } \\
\text { tailed) }\end{array}$ \\
\cline { 2 - 6 } $\begin{array}{c}\text { Equal } \\
\text { variances } \\
\text { assumed } \\
\begin{array}{c}\text { Equal } \\
\text { variances } \\
\text { not } \\
\text { assumed }\end{array}\end{array}$ & -417 &, 519 & $-1,429$ & 369 &, 154 \\
\hline
\end{tabular}

Based on the output result above, the significance 0.154 . Thus, the significance of $>0.05(0,154>0.05)$ is then $\mathrm{H} 0$ acceptable. So it can be concluded that the parents ' income data group has the same variance, so Test T (Independent Sample T-Test) using the equal value variance assumed.

Table 5. Description of financial Literacy statistics

\begin{tabular}{|l|l|l|l|l|l|}
\hline Variable & N & Minimum & Maximum & Mean & $\begin{array}{c}\text { Std } \\
\text { Deviation }\end{array}$ \\
\hline $\begin{array}{l}\text { Financial } \\
\text { literacy }\end{array}$ & 371 & 43 & 114 & 71,04 & 12,182 \\
\hline
\end{tabular}

The mean value (average) based on the research data is interpreted in the criteria of financial literacy according to Chen and P. Volpe (1998). It was then divided into three categories of groups, namely: $(1) \leq 60 \%$, which 
means individuals have a common knowledge (financial literacy), (2) 60\%-79\%. This means individuals have sufficient or moderate finan-cial knowledge, (3) $\geq 80 \%$ indicating that individu-als have high financial knowledge. It can be con-cluded that the student's overall financial literacy rate is in the medium category with a mean value of 71.04 .

\subsection{Results}

It can be concluded that there is no influence over gender on financial literacy. In comparison, the research conducted by Arceo \& Villagómez (2017) states that women are higher on the cognitive level towards financial literacy than men [31]. This research is in line with the research conducted by Homan (2015), stating that gender has no significant influence over financial literacy [23] and confirmed the research results of Suherman et al. (2020) [22], stating that female or male students have no distinction in the knowledge of financial literacy.

Confirming the hypothesis testing outcome be-tween income and financial literacy indicates that the parents' income has the same variance. It can therefore be concluded that there is no influence of financial literacy according to parental education. However, this is in line with Erner, Goedde, \& Oberste (2016), stating that revenues have no significant effect on financial literacy [32]. However, it differs from the study conducted by Nidar \& Bestari (2012) [26], which suggests that parents ' income is influential about financial literacy.

The level of understanding of student financial literacy is in the medium category. Therefore, the increased understanding of financial literacy is not enough with learning in the classroom and outside of class. The form of activity can be a simple practice to the field, training, and seminars on financial management to better impact students' financial decision-making. This research has some limitations in its implementation. The limitation of this research area is research conducted using questionnaires. Besides, the authors cannot provide direct supervision to each respondent during the questionnaire. The suggestions for subsequent studies are expected to identify and determine more about variables that have not been in line with the theory, adding to the variable factors affecting financial literacy, using different sampling methods and different analytical techniques. It can also maximize the research instrument to obtain maximum research results.

\section{CONCLUSIONS}

Based on the results of the research through da-ta processing using SPSS V. 25 with data collection through the dissemination questionnaire can be con-cluded that: (1) Students ' financial literacy rate in the medium category; (2) There is no difference in the financial literacy of students, according to the gender and the income of parents.

\section{REFERENCES}

[1] T. Jappelli and M. Padula, "Investment in financial literacy and saving decisions," J. Bank. Financ., vol. 37, no. 8, pp. 2779-2792, 2013, doi: 10.1016/j.jbankfin.2013.03.019.

[2] OCDE, PISA 2012 Results: Students and Money (Volume VI), vol. VI, no. Volume VI. 2012.

[3] P. Bhushan, "Financial Literacy and its Determinants," Int. J. Eng. , Bus. Enterp. Appl. ( IJEBEA ), no. July, 2014.

[4] KUSUMANINGTYAS and N. Canda Sakti, "Pengaruh Literasi Keuangan Dan Gaya Hidup Terhadap Perilaku Konsumtif Siswa Kelas Xi Ips Di Sma Negeri 1 Taman Sidoarjo,” J. Pendidik. Ekon., vol. 5, no. 3, 2017.

[5] Lusardi and O. S. Mitchell, "Financial literacy: Evidence and implications for financial education," Trends and issues, pp. 1-18, 2009.

[6] Haiyang Chen and P. Volpe, "An Analysis of Personal FInance Literacy Among College Student," Zhongguo Jiguang/Chinese J. Lasers, vol. 43, no. 8, pp. 107-128, 1998, doi: 10.3788/CJL201643.0811001.

[7] D. Saepuloh and S. Rodiah, "Penerapan Pembelajaran Kooperatif Melalui Model Group Investigation Untuk Meningkatkan Literasi Ekonomi Siswa,” J. Pendidik. Ekon., vol. 13, no. 1, pp. 30-41, 2020.

[8] Atkinson, "Measuring Financial Literacy.” 2010.

[9] Otoritas Jasa Keuangan, "Survei Nasional Literasi dan Inklusi Keuangan 2016 (National Literacy and Financial Inclusion Survey 2016), Surv. Rep., pp. 1-26, 2016.

[10]OJK, "Strategi Nasional Literasi Keuangan Indonesia (Revisit 2017)," Otoritas Jasa Keuang., pp. 1-99, 2017.

[11]S. J. Huston, "Measuring Financial Literacy," J. Consum. Aff., vol. 44, no. 2, pp. 296-316, 2010, doi: 10.1111/j.1745-6606.2010.01170.x.

[12]Lusardi and O. S. Mitchell, "The Economic Importance of Financial Literacy: Theory and Evidence," SSRN Electron. J., 2013, doi: 10.2139/ssrn.2260193.

[13] M. Batty, J. M. Collins, and E. Odders-White, "Experimental evidence on the effects of financial education on elementary school students' 
knowledge, behavior, and attitudes," J. Consum. Aff., vol. 49, no. 1, pp. 69-96, 2015, doi: 10.1111/joca.12058.

[14] J. A. Molina Marfil, O. D. Marcenaro Gutiérrez, and A. Martín Marcos, "Educación financiera y sistemas educativos en la OCDE: un análisis comparativo con datos PISA 2012," Revista de Educacion, no. 369. pp. 85-108, 2015, doi: 10.4438/1988-592X.

[15]R. S. W. Riski Amaliyah, “ANALISIS FAKTOR YANG MEMPENGARUHI TINGKAT LITERASI KEUANGAN DI KALANGAN UMKM KOTA TEGAL," Manag. Anal. J., vol. 4, no. 3, pp. 252$257,2015$.

[16] H. C. Khusaini, Ramdani and R. Ambarumanti, "The Influence of Shopping and Gender Differences on Online Shopping,” J. Pendidik. Ekon. Bisnis, vol. 7, no. 1, pp. 22-30, 2019.

[17] N. Damayanti, "Perbedaan jenis kelamin terhadap minat berwirausaha mahasiswa jurusan pendidikan ekonomi universitas negeri surabaya," pp. 1-16, 2013 .

[18]N. S. Mahdzan and S. Tabiani, "The impact of financial literacy on individual saving: An exploratory study in the malaysian context," Transform. Bus. Econ., vol. 12, no. 1, pp. 41-55, 2013.

[19] G. Nicolini, B. J. Cude, and S. Chatterjee, "Financial literacy: A comparative study across four countries," vol. 37, no. 2006, pp. 689-705, 2013, doi: $10.1111 /$ ijcs. 12050 .

[20] Aisyah and D. Saepuloh, "The Implementation of Islamic Financial Literacy through 'Kencleng' Program in School," KnE Soc. Sci., vol. 3, no. 13, p. 148, 2019, doi: 10.18502/kss.v3i13.4202.

[21]N. Garg and S. Singh, "Financial literacy among youth," Int. J. Soc. Econ., vol. 45, no. 1, pp. 173186, 2018, doi: 10.1108/IJSE-11-2016-0303.

[22] Suherman, E. Puspa, K. Wardani, E. E. Program, and U. I. S. Tangerang, "Analisis Literasi Keuangan Mahasiswa di FKIP UNIS Tangerang," vol. 13, no. 1, pp. 18-29, 2020.

[23]H. S. Homan, "Comparative Study of Students Financial Literacy And Its Demographic Factors," pp. 106-111, 2015, doi: 10.2991/iceb-15.2015.16.

[24]N. Sofia and A. Irianto, "Pengaruh Pendapatan Orang Tua, Kelompok Acuan, dan Hasil Belajar Ekonomi Terhadap Literasi Keuangan Mahasiswa Fakultas Ekonomi Universitas Negeri Padang," J. Kaji. Pendidik. Ekon., vol. 3, no. 1, pp. 2-18, 2016.
[25] Herman Hadiyanto, "PENGARUH PENDIDIKAN, PEKERJAAN DAN PENDAPATAN ORANG TUA TERHADAP PRESTASI BELAJAR EKONOMI PADA SISWA SMA," J. Ekon. Pendidik. Dan Kewirausahaan, vol. 2, no. 2, pp. 171-185, 2014.

[26] S. R. Nidar and S. Bestari, "Personal Financial Literacy Among University Students (Case Study at Padjadjaran University Students, Bandung, Indonesia)," World J. Soc. Sci., vol. 2, no. 4, pp. $162-171,2012$.

[27]F. Margaretha and R. A. Pambudhi, "Tingkat Literasi Keuangan Pada Mahasiswa S-1,” Tingkat Literasi Keuang. Pada Mhs. S-1 Fak. Ekon., vol. 17, no. 1, pp. 76-85, 2015, doi: 10.9744/jmk.17.1.76.

[28]L. Sulaiman, "Investigating the factors influencing the life insurance market in Ethiopia," Probl. Perspect. Manag., vol. 13, no. 2, pp. 152-160, 2015.

[29] M. D. Radityas and A. Pustikaningsih, "Analysis of the Factors That Influence Students' Level of Financial Literacy," J. Pendidik. Akunt. Indones., vol. 17, no. 1, pp. 42-56, 2019, doi: 10.21831/jpai.v17i1.26336.

[30]E. O. Arceo-Gómez and F. A. Villagómez, "Financial literacy among Mexican high school teenagers," Int. Rev. Econ. Educ., vol. 24, pp. 1-17, 2017, doi: 10.1016/j.iree.2016.10.001.

[31]N. T. Herawati, “Tingkat Literasi Keuangan Mahasiswa Serta Faktor-Faktor yang Mempengaruhinya,"' Semin. Nas. Ris. Inov. 2017, pp. 131-137, 2017.

[32]C. Erner, M. Goedde-Menke, and M. Oberste, "Financial literacy of high school students: Evidence from Germany," J. Econ. Educ., vol. 47, no. 2, pp. 95-105, 2016, doi: 10.1080/00220485.2016.1146102. 